\title{
The Validity of Okun's Law in North Macedonia
}

\author{
Despina Tumanoska (Corresponding author) \\ FINANCE THINK - Economic Research \& Policy Institute \\ Str. Frederick Chopin 1/2, 1000 Skopje, Republic of North Macedonia \\ Tel: 389-7533-6174Ｅ-mail: Despina.tumanoska@ financethink.mk
}

Received: April 16, 2019 Accepted: April 30, 2019 Published: May 22, 2019

doi:10.5296/ber.v9i2.14659

URL: https://doi.org/10.5296/ber.v9i2.14659

\begin{abstract}
This paper investigates the relationship between unemployment rates (youth and total) and GDP growth in North Macedonia, within the context of Okun's Law. The econometric analysis of the paper is based on The Auto-regression Distributed Lags Model, using data for the period 1991-2017 collected from different data basis. The econometric analysis suggests that there is a statistically significant long-run relationship between the GDP growth and total unemployment in North Macedonia, at the $1 \%$ level of probability. In particular, the findings show that a $1 \%$ increase in the economic growth will lead to decrease of the total unemployment for $2.57 \%$. No short- or long-run relationship between GDP growth and youth unemployment was detected.
\end{abstract}

Keywords: Okun's law, Unemployment, Youth unemployment, Economic output, North Macedonia

\section{Introduction}

Macedonian labor market improved significantly recent years, given that in a period of 10 years, the unemployment rate decreased by 10 percentage points. In $2017,22.4 \%$ of the total labor force in the country was unemployed. But, the unemployment rate of youth aged 15-24 remained at very high level, which is of serious societal concern. In 2017, every second youth who was actively seeking a job, was unemployed. The unemployment rate of youth was $46.9 \%$ in 2017, far above the EU-28 average of 19.6\%. Another concern is the low activity rate of these persons, which deteriorated from $35.9 \%$ in 2007 by $32.8 \%$ in 2017 . According to the Ministry of labor and social policy, main reasons for such situation are: increased time spent in education, reduced employment opportunities, difficulties during the school to work transition process, mismatch between the skills supply and demand at the labor market and the reluctance of the employers to cover the costs for initial on-the-job training of the young employees. 
The unemployment is a serious worrying phenomenon that has negative influence on the unemployed individual and on the society in general. On individual level, the unemployment leads to lower psychological and physical health, suicide and mortality (Petreski, Mojsoska-Blashevski \& Bergolo, 2017; Wanberg, 2012; Paul \& Moser, 2009). Msigwa and Kipesha (2013) noted that youth unemployment may lead to malnutrition, stress, depression and even heart problems. Youth who cannot find a job, could engage in criminal activities and violence, which take them further away from the labor market (Sum, Fogg \& Mangum, 2002). On economic level, the unemployment is the major instigator of the poverty and income inequality. It results in social exclusion, higher state costs for unemployment benefits, lower taxes and social contributions and lost production.

The determinants of unemployment are divided in three groups: 1) cyclical conditions, 2) demographic, individual, social and structural conditions, and 3) policies and institutions (Brada, Marelli \& Signorelli, 2014). Many economists tried to estimate the relationship between the economic output and total unemployment rate. Lee (2000) estimated the relationship between the economic output and unemployment in OECD countries, and found different level of relationship between the countries, but concluded that the relationship is elsewhere valid. Using Error Correction Model, Akeju and Olanipekun (2014) found a weak relationship between the economic output and unemployment in Nigeria: 1\% change in unemployment will lead to $0.097 \%$ increase in the economic output. Dare and Hek (2016) investigated the validity of Okun's law in Curacao. Using ARDL model they found that on a long-run, a $1 \%$ increase in the real GDP growth leads to a $2.3 \%$ decrease of unemployment rate. On short-run, the effect is a bit smaller and leads to a $1.9 \%$ decrease in unemployment rate. Zagler (2003) investigated the existence of this law in France, United Kingdom, Germany and Italy, and found that a negative relationship between unemployment and economic growth exist only at short-run, while on a long-run, it is positive. Javeid (2005) investigated the relationship for Pakistan, and found that a $1 \%$ increase in GDP will lead to $2.8 \%$ decrease in the total unemployment rate. The study of Arshad (2010) proved the existence of the law in Sweden, estimating that a $1 \%$ in GDP will lead to $2.2 \%$ decrease in the unemployment. Ting and Ling (2011) found a significant Okun's coefficient of $-1.8 \%$ in Malaysia.

There is also a specific literature which estimates the relationship between the youth unemployment and the economic output. For instance, Pastore and Giuliani (2015) confirmed that the economic climate and the population structure affect the youth unemployment rate in 5 panels of countries. The higher participation of youth at the country's population have negative effect on the youth unemployment rate, while the higher GDP per capita growth leads to lower youth unemployment. The latter was investigated by Zyra (2013) who found that, in Poland, an increase of the output growth for 1 percentage points contributes to a 0.37 percent decrease in youth unemployment rate. She also found that the youth unemployment is closely related to the general unemployment in Poland, and that an increase of a percentage point in the general unemployment will be transformed to 0.46 percent higher youth unemployment. Gocer and Erdal (2015) estimated the relationship between youth unemployment and economic growth in 18 Central and Eastern European countries, and 


\section{Macrothink}

Business and Economic Research

ISSN 2162-4860

2019, Vol. 9, No. 2

found that one point decrease above average economic growth rate is associated with a $1.13 \%$ decrease in youth unemployment.

In what follows, the next section reviews briefly Okun's Law in connection with this work. Section 3 gives a descriptive analysis of the GDP growth and unemployment in North Macedonia. Section 4 describes the used data and methodology. Section 5 gives the results and the last section concludes.

\section{Okun's Law}

Arthur Okun (1962) is the first economist who empirically studied the relationship between the unemployment and economic growth, and postulated that $1 \%$ increase in the growth rate above its trend rate will lead to only $0.3 \%$ reduction in the unemployment rate. In order to fit in the current economic situation, the Okun's law changed over time, so another version is that a percentage point increase in unemployment causes a $2 \%$ fall in GDP.

The literature knows four versions of Okun's law, but the most commonly used models are these two:

- The difference model

$$
\mathrm{Ut}-\mathrm{Ut}-1=\alpha+\beta(\mathrm{Yt}-\mathrm{Yt}-1)+\varepsilon \mathrm{t}
$$

uses the first difference of the variables (GDP growth and unemployment rate), and

- The gap version

$$
\mathrm{Ut}-\mathrm{Ut}^{*}=\alpha+\beta\left(\mathrm{Yt}-\mathrm{Yt}^{*}\right)+\varepsilon \mathrm{t}
$$

uses the difference between actual and natural unemployment, and actual and potential GDP at the same period.

In both models, central coefficient is $\beta$, also known as Okun's coefficient, with a negative value, meaning that GDP growth should lead to decrease in the unemployment, and vice versa.

Trying to investigate the existence of the Okun's law in North Macedonia, this paper uses the difference model, presented through the following equations:

- The difference model for investigating the relationship between total unemployment and economic growth

$$
\Delta \mathrm{U}=\alpha+\beta(\Delta \mathrm{gdp})
$$

where $\Delta \mathrm{U}$ is the first difference of total unemployment rate, $\Delta \mathrm{gdp}$ is the first difference of the economic growth rate and $\beta$ is the Okun's coefficient.

- The difference model for investigating the relationship between youth unemployment and economic growth

$$
\Delta \mathrm{YU}=\alpha+\beta(\Delta \mathrm{gdp})
$$




\section{Macrothink}

where $\Delta U$ is the first difference of youth unemployment rate, $\Delta \mathrm{gdp}$ is the first difference of the economic growth rate and $\beta$ is the Okun's coefficient.

\section{Initial Inspection in the Unemployment and Economic Growth in North Macedonia}

This section describes the two variables that will be used in the econometric model below. Figure 1 presents the trend of the total unemployment rate, youth unemployment rate and GDP growth rate in the period 2000-2017. It shows that the youth unemployment is more than double higher than the total unemployment rate, ranging from $47 \%$ to $65.6 \%$. The higher total unemployment rate of $37.2 \%$ was recorded in 2005 , while the total unemployment rate in 2017 was 22.4\%. The largest reductions in GDP have been recorded in 2001, due to the political crisis, and 2008 due to the world economic crisis.

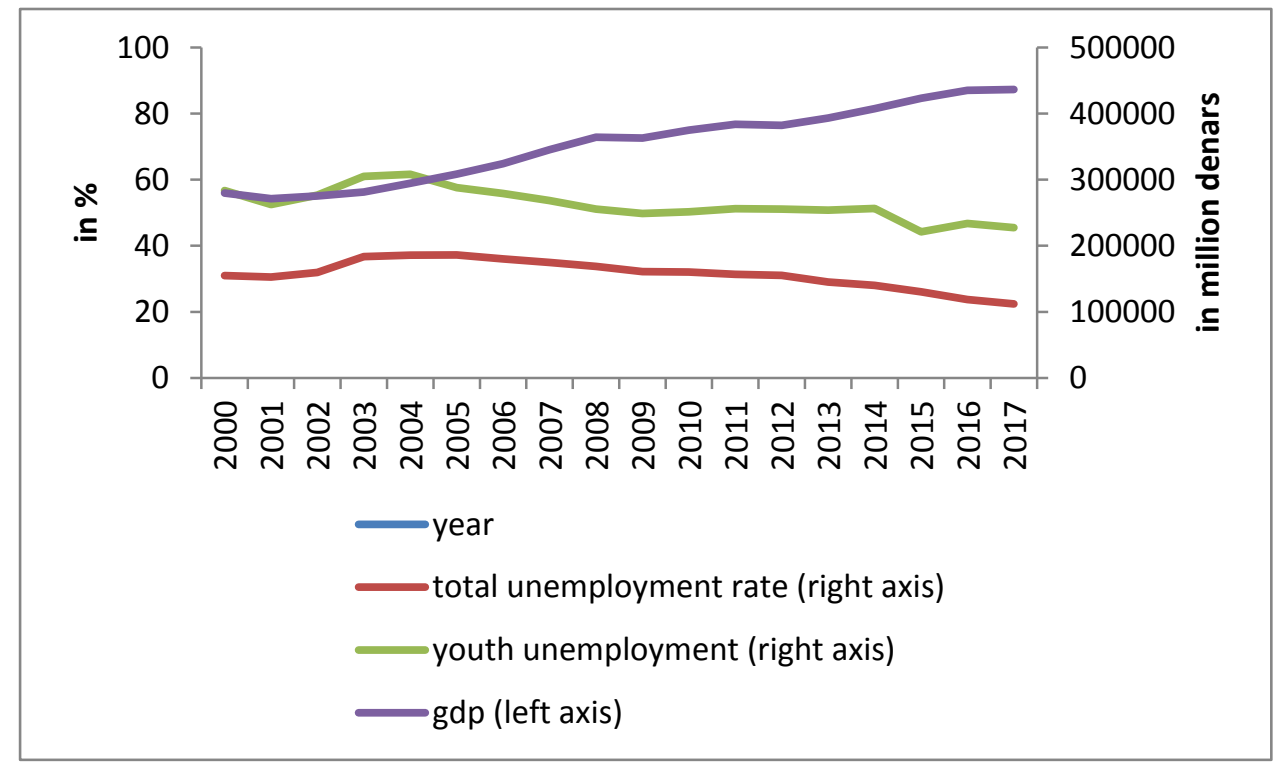

Figure 1. Movement of the variables in the period 2000 - 2017

Figure 2 shows a potential negative relationship between the variables, suggesting that increase (decrease) in GDP will lead to decrease (increase) in the unemployment rates.
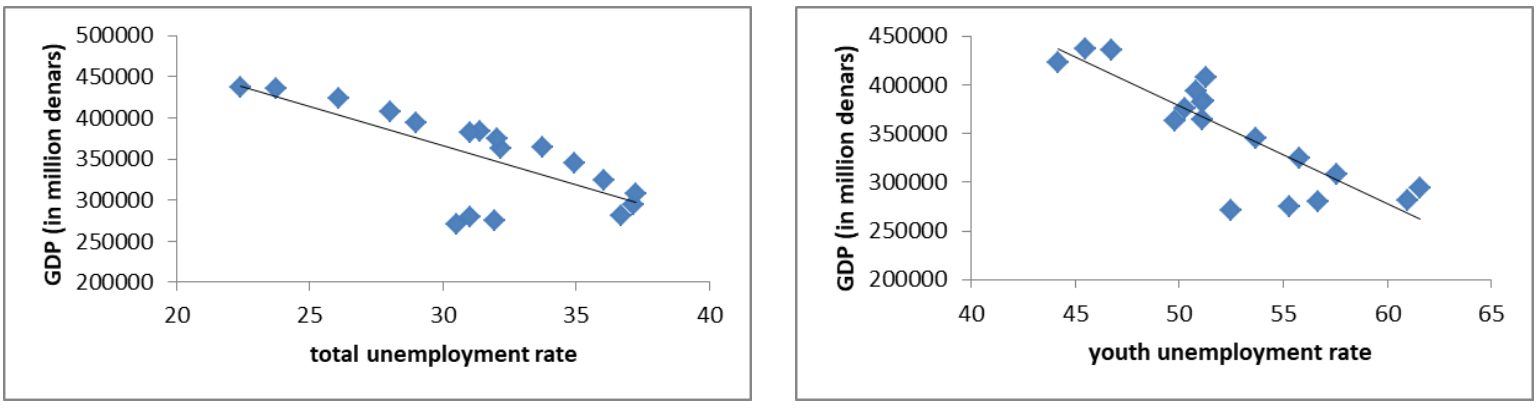

Figure 2. Relationship between GDP and unemployment rates

\section{Data and Methodology}

This study tries to investigate the relationship between the economic growth and the unemployment rates (of total population and of youths) in Republic of North Macedonia for 
the period 1991 - 2017. We use annual data for the unemployment rate, youth unemployment rate and economic output collected from the data bases of the World Bank, the International Monetary Fund and national statistical office. Total unemployment refers to the share of the labor force that is without work but able for and seeking employment. Youth unemployment refers to the share of the labor force ages 15-24 without work but able for and seeking employment. The annual percentage growth rate of GDP is expressed at market prices based on constant 2010 US dollars.

We employ an auto-regressive distributed lag model (ARDL) to correctly estimate the $\beta$ coefficient. This is done for several reasons. First, ARDL can be used when variables are integrated of order one, order zero or mixed orders. Second, the bounds testing procedure of the ARDL technique is more efficient for small and finite data series. Third, the ARDL technique generates unbiased estimates for the long-run model.

The generalized ARDL (p, q) model is specified as:

$$
\mathrm{Yt}=\Upsilon_{\mathrm{ot}}+\Sigma \mathrm{pi}=1 \delta \mathrm{jYt}-1+\Sigma \mathrm{qi}=1 \beta \mathrm{jXt}-1+\varepsilon \mathrm{jt}
$$

Where Yt is a vector and the variables in $\mathrm{Xt}$ are allowed to be purely $\mathrm{I}(0)$ or $\mathrm{I}(1)$ or co-integrated; $\beta$ and $\delta$ are coefficients, $\Upsilon$ is the constant, $j=1 \ldots \mathrm{k}, \mathrm{p}$ and $\mathrm{q}$ are optimal lag orders where $\mathrm{p}$ is used for the dependent variable and $\mathrm{q}$ is used for independent variable, $\mathrm{j}$ t is a vector of error terms. It means that the dependent variable is a function of its lagged value, the current and lagged values of the exogenous variables in the model.

The ARDL technique is a three-step process, starting with an estimation of the optimal lag length chosen according to the Akaike Information Criteria (AIC). Then, a bounds test where the null hypothesis being that there is no co-integration between the GDP and the unemployment is conducted. The estimated value is compared with the critical value from Pesaran, Shin and Smith (2001), and the null hypothesis is rejected if the test statistics is above the upper critical value. If there seems to be a long-run relationship, during the third step we estimate the error correction model (ECM), which provides the speed of adjustment back to long-run equilibrium after a short-run shock.

$$
\Delta \mathrm{Yt}=\alpha 1+\Sigma \delta \mathrm{i} \Delta \mathrm{Yt}-\mathrm{I}+\Sigma \omega \Delta \mathrm{Xt}-\mathrm{I}+\rho \mathrm{ECTt}-1+\varepsilon \mathrm{t}
$$

\section{Results}

First, we examine the integration characteristics of the main variables, i.e. if they contain a unit root. Datasets with unit roots follow a stochastic trend, and are non-stationary. Non-stationarity implies that data series do not have constant mean, constant variance and constant co-variance over time. To test the stationarity of our variables, we are employing two formal tests, Augmented Dickey-Fuller and Phillips-Perron tests, which are often applied and details on them can be found, for example, in Wooldrige (2007). The null hypothesis in both tests is that the series is non-stationary, i.e. contains unit root. 
Table 1. Unit roots tests

\begin{tabular}{|l|l|l|l|l|l|l|}
\hline Unit root test & \multicolumn{4}{|l|}{$\mathrm{t}$ statistics } \\
\hline & YU & $\mathrm{U}$ & GDP & YU_d1 & U_d1 & GDP_d1 \\
\hline Augmented Dickey-Fuller & -0.803 & -0.122 & $-2.702 *$ & $-4.124 * * *$ & -1.559 & $-6.140 * * *$ \\
\hline Phillips-Perron & -1.065 & -1.005 & -2.628 & $-4.125 * * *$ & -1.404 & $-6.232 * * *$ \\
\hline
\end{tabular}

Source: Author's estimations.

Note: $* * * * * *$ signify that the null hypothesis (has unit root) is rejected at the 10,5 and $1 \%$ level. The number of time lags is automatically chosen based on the Schwarz information criterion.

The results of the unit root tests are shown in Table 1. If we analyze the series of youth unemployment and GDP growth, the tests shows that both are non-stationary, which is additionally supported with the descriptive analysis shown in Figure 1. The results suggest that the series for youth unemployment and GDP growth are non-stationary, while the Augmented Dickey-Fuller test rejects the null hypothesis of a unit root, but only at the $10 \%$ level of probability, and only for the economic growth variable. Hence, we conclude that variables are probably non-stationary in levels. After first differencing, series for youth unemployment and GDP become stationary, which means that they are integrated of order $1-$ I(1). The series for total unemployment are still non-stationary.

\subsection{Total Unemployment and GDP}

Before proceeding with the bounds test, we must specify the number of lags to include, given that the F-statistics for co-integration is sensitive to the lag length. The optimal number of lags used in the equation is the one from Akaike Information Criterion (AIC), which is 1 for the total unemployment and 2 for the GDP growth rate. It means that our model is ARDL(1 2).

Table 2. Bounds test

\begin{tabular}{|l|l|}
\hline Critical bounds & Critical value \\
\hline $\mathrm{F}$ & 8.080 \\
\hline $\mathrm{I}(1)^{* * *}$ & 4.78 \\
\hline $\mathrm{I}(1)^{* *}$ & 5.73 \\
\hline $\mathrm{I}(1)^{*}$ & 7.84 \\
\hline
\end{tabular}

Note: $* * * * *$ and $*$ refers to $10 \%, 5 \%$ and $1 \%$ level of significance, respectively.

The Bounds test, whose results are shown in Table 2, suggests that there is a long-run relationship between the variables, given that $F$ value is above the upper bound for $I(1)$. It means that we could employ a model that separates and measures both short- and long-run relationships, and the most appropriate is ARDL including error correction model, presented in equation (2). The results are presented in Table 3. 
Table 3. Results

\begin{tabular}{|l|l|}
\hline $\begin{array}{l}\text { Dependent variable } \\
\text { U - total unemployment }\end{array}$ & \\
\hline Short run & $0.49 *$ \\
GDP & $(0.133)$ \\
\hline Long-run & $-2.57 * *$ \\
GDP & $(1.098)$ \\
\hline Speed of adjustment coefficient & $0.2 * * *$ \\
& $(0.103)$ \\
\hline
\end{tabular}

Note: $* * * * *$ and $*$ suggests rejection of null hypothesis on $10 \%, 5 \%$ and $1 \%$, respectively.

The results suggest that there is a negative long-run relationship between the total unemployment and GDP growth, suggesting that a $1 \%$ increase in GDP leads to $2.57 \%$ decrease in the total unemployment rate. On short-run, the coefficient is positive, meaning that the Okun's law is not valid for short-run. These results are in line with the Okun's law and the literature described in Section 1. The adjustment term is positive and statistically significant. The statistical significance of the adjustment term suggests that unemployment is driven by the economic growth. But the positive value implies that the imbalance in their relationship is not balanced after a shock, but the imbalance further deepens.

\subsection{Youth Unemployment and GDP}

To examine the relationship between the youth unemployment and GDP growth, we are using an optimal lag length of 1 for youth unemployment and 3 for GDP growth, meaning that our model is ARDL(1 3).

Table 4. Bounds test

\begin{tabular}{|l|l|}
\hline Critical bounds & Critical value \\
\hline $\mathrm{F}$ & 0.305 \\
\hline $\mathrm{I}(0)^{* * *}$ & 4.04 \\
\hline $\mathrm{I}(0)^{* *}$ & 4.94 \\
\hline $\mathrm{I}(0)^{*}$ & 6.84 \\
\hline
\end{tabular}

Note: $* * *, * *$ and $*$ refers to $10 \%, 5 \%$ and $1 \%$ level of significance, respectively.

The results of the Bounds test are shown in Table 4. Given that the F value falls below the lower values for $\mathrm{I}(0)$ values for all significance levels, we cannot reject the null hypothesis, meaning that there is no long-run relationship between the youth unemployment and GDP growth.

According to the finding that the variables are not co-integrated on the long run, we are proceeding with estimating of their short-run relationship, using ARDL - auto-regressive distributed lag model. However, the $\beta$ coefficient for the short-run relationship is insignificant, meaning that the variables are not co-integrated nor on short-run. It means that the Okun's law in terms of youth unemployment is not valid in North Macedonia, neither on long, nor on 
short-run.

\section{Conclusion}

This paper investigates the relationship between unemployment rates (total and youth) and GDP growth in North Macedonia, in the context of Okun's Law, in the period 1991-2017, using Auto-regressive Distributed Lag Model (ARDL). The research started with examination of the existence of unit root. The tests shows that the youth unemployment rate and the GDP growth are integrated of order one, while the total unemployment is $I(0)$. The Bounds test for the relationship between total unemployment and GDP growth suggest that there is long-run relationship between these variables, suggesting that a $1 \%$ increase of GDP will lead to $2.57 \%$ decrease in the total unemployment rate. The Bounds test for the relationship between the youth unemployment and GDP growth showed that there is no co-integration between the variables, which was a good ground for estimating only the short-run relationship. However, the coefficient for the short-run relationship is insignificant, suggesting that even on short-run, these two variables are not co-integrated.

These findings suggest that, for tackling youth unemployment rates, more targeted and youth-specific measures and programs should be put in place. Several policy recommendations may be an introduction of dual education, compulsory internship programs, introduction of work-based learning, involvement of employers in the curricula design, etc.

\section{References}

Akeju, K., \& Olanipekun, D. (2014). Unemployment and economic growth in Nigeria. Journal of Economics and Sustainable Development, 5(4), 138-144.

Arshad, Z. (2010). The validity of Okun's Law in Swedish economy (Master Thesis, Stockholm University). [Online] Available:

http://www.ne.su.se/polopoly_fs/1.25832.1318427751!/menu/standard/file/Zeeshan_Arshad.p df

Brada, J., Marelli, E., \& Signorelli, M. (2014). Young people and the labor market: Key determinants and new evidence. Comparative Economic Studies, 56, 556-566.

https://doi.org/10.1057/ces.2014.30

Dare, S., \& Hek, A. (2016). The validity of Okun's Law in Curacao. Central Bank of Curacao Working Paper. [Online] Available:

https://www.centralbank.cw/uploads/files/The\%20Validity\%20of\%20Okuns\%20law\%20in\% 20Cura\%C3\%A7ao.pdf

Gocer, I., \& Erdal, L. (2015). The relationship between youth unemployment and economic growth in Central and Eastern European countries: An empirical analysis. Journal of the Faculty of Economics and Administrative Sciences, 5(1), 173-188.

Javeid, U. (2005). Okun's Law: Empirical evidence from Pakistan 1981-2005. (Master Thesis. Södertörn University). [Online] Available:

http://www.diva-portal.org/smash/get/diva2:525872/FULLTEXT01.pdf 


\section{Macrothink}

Business and Economic Research ISSN 2162-4860 2019, Vol. 9, No. 2

Lee, J. (2000). The robustness of Okun's Law: Evidence from OECD countries. Journal of Macroeconomics, 22(2), 331-356. https://doi.org/10.1016/S0164-0704(00)00135-X

Msigwa, R., \& Kipesha, E. (2013). Determinants of youth unemployment in developing countries: Evidence from Tanzania. Journal of Economics and Sustainable Development, 4(14), 67-76. https://doi.org/10.5296/ber.v4i1.5077

Ting, N., \& Ling, L. (2011). Okun's Law in Malaysia: An auto-regressive distributed lag (ARDL) approach with Hodrick Prescott HP Filter. Unpublished manuscript. [Online] Available: https://www.researchgate.net/publication/227439496

Okun, A. (1962). Potential GNP: Its measurement and significance. American Statistical Association: Proceedings of the Business and Economic Statistics Section, pp. 98-104.

Pastore, F., \& Guiliani, L. (2015). The determinants of youth unemployment: A panel data analysis. CRISEI - Universita di Napoli Working Paper No. 02.

Paul, K., \& Moser, K. (2009). Unemployment impairs mental health: meta-analysis. Journal of vocational behaviour, 74(3), 264-282. https://doi.org/10.1016/j.jvb.2009.01.001

Pesaran, M., Shin, Y., \& Smith, R. (2001). Bounds testing approaches to the analysis of level relationship. Journal of Applied Econometrics, 16(3), 289-326.

https://doi.org/10.1002/jae.616

Petreski, M., Mojsoska-Blazhevski, N., \& Bergolo, M. (2017). Labor-market scars when youth unemployment is extremely high: Evidence from Macedonia. Eastern European Economics, 55(2), 168-196. https://doi.org/10.1080/00128775.2016.1261631

Sum, A., Fogg, N., \& Mangum, G. (2002). Confronting the youth demographic challenge: The labor market prospects of out-of-school young adults. Sar Levitan Center For Social Policy Studies, Johns Hopkins University, Baltimore.

Wanberg, C. (2012). The individual experience in unemployment. Annual Reviews, 63, 369-396. https://doi.org/10.1146/annurev-psych-120710-100500

Wooldridge, J. M. (2007). Introductory Econometrics: A Modern Approach (3rd ed.). London: The MIT Press.

Zagler, M. (2003). A vector error correction model of economic growth and unemployment in major European countries and an analysis of Okun's law. Applied Econometrics and International Development, 3(3), 93-118.

Zyra, J. (2013). Econometric models and data processing framework for monitoring of youth labor market in Poland. Information Systems in Management, 2(4), 323-334.

\section{Copyright Disclaimer}

Copyright for this article is retained by the author(s), with first publication rights granted to the journal.

This is an open-access article distributed under the terms and conditions of the Creative Commons Attribution license (http://creativecommons.org/licenses/by/3.0/). 